\title{
ENSINAR A LER PARA ALÉM DO VISÍVEL: DO SENTIDO DE LÍNGUA AO SENTIDO DE DISCURSO
}

\author{
Ilana da Silva Rebello
}

\begin{abstract}
RESUMO
Este trabalho tem por objetivo, a partir da análise de duas capas de revista, mostrar que ler um texto não é apenas dar um sentido a ele, mas perceber a sua plurissignificação. Para tanto, além de contribuiçôes da Linguística Textual, também tomamos por base algumas contribuiçôes da Semiolinguística, como a noção de "sentido de língua" e "sentido de discurso" proposta por Charaudeau.
\end{abstract}

PALAVRAS-CHAVE: leitura; interpretação; capas de revista.

odas as sociedades têm uma prática discursiva que não se volta, necessariamente, para uma prática objetiva imediata. Os discursos da socie-

dade fazem parte de uma tradição, dando identidade a essa sociedade.

A escrita não foi o primeiro dos mecanismos de fixação cultural utilizado pela humanidade. A transmissão oral da tradição, o uso de rituais e da dança, o apelo às artes visuais precederam a escrita.

Hoje, sabemos que a leitura pode ser fonte de prazer, quando se consegue penetrar no sentido por meio da percepção mais aprofundada do jogo de palavras que constrói o texto. A verdadeira leitura ultrapassa os significantes e chega aos possíveis significados permitidos pelo texto. E aqui pode-se citar a distinção estabelecida por Charaudeau (1995; 1999) entre sentido de língua e sentido de discurso, tendo como base a noção referencial da língua.

Tal distinção é importante porque mostra a diferença entre dois processos tomados comumente como idênticos - a compreensão e a interpretaçáo. $\mathrm{O}$ ato de compreensáo se limita a reconhecer o sentido de língua; o ato de interpretação coloca esse sentido de lingua em relação com as condiçóes que presi- 
dem a finalização prática do ato de comunicação. E, para entender os sentidos de um texto, o leitor precisa ultrapassar o sentido de lingua e chegar ao sentido de discurso. Fazer inferências, ultrapassar o meramente visível não é tarefa muito fácil, daí a necessidade de um trabalho sistemático.

Para Charaudeau (1995; 1999, p. 29), o sentido de lingua refere-se ao mundo de maneira transparente, construindo uma imagem de um locutor-ouvinte-ideal, ou seja, uma visão simbolizada referencial do mundo. O sentido linguístico trabalha apenas com um signo linguístico capaz de associar o significante a um significado pleno nas suas relaçóes sintagmáticas e paradigmáticas. $\mathrm{O}$ movimento de estruturação de sentido é centrípeto, atribuindo às palavras traços distintivos, pois age de acordo com uma sistematicidade intralinguística, baseada no sistema.

Já o sentido discursivo caracteriza-se por sua opacidade em relação ao mundo, no momento em que se refere ao próprio processo de enunciação e a um sujeito que se define em relações múltiplas de intersubjetividade. Assim, o signo remete a algum significado, mas este não pode ser visto a partir de um valor absoluto e autônomo, mas apenas como portador de um sentido potencial que precisa ser articulado com outros signos e com a prática social para que seja construído o sentido discursivo.

No sentido de discurso, o significante pode ter múltiplos sentidos, pois, para Charaudeau (1995, 1999), as palavras não valem por si, mas quando estáo relacionadas a um "ailleurs" (contexto). Nesse caso, o sujeito que interpreta um texto não busca o sentido intrínseco das palavras (significado referencial), mas seu valor social e seu peso na troca interativa.

O sentido discursivo, ao contrário do sentido linguístico, é construído como resultante da força centrifuga que relaciona as palavras e sequências portadoras de sentidos de língua com outras palavras e sequências que se acham registradas na memória de experiência do sujeito.

Dessa forma, o sentido de lingua resulta de um processo semântico-linguístico de ordem categorial e o sentido de discurso resulta de um processo semântico-discursivo de ordem inferencial.

Ao mobilizar as regras de comunicação (langue), o sujeito comunicante constrói um sentido literal ou explícito, ou seja, um sentido de língua que se mede segundo critérios de coesão. Por outro lado, há o sentido indireto ou implícito, ou seja, um sentido de discurso, que se mede segundo critérios de coerência. 
O processo de ordem categorial que termina no reconhecimento do sentido de língua pode se chamar "compreensão". E o processo duplo (discursivo e situacional) de ordem inferencial, que leva ao reconhecimento - construção do sentido de discurso problematizado e finalizado - pode ser chamado de "interpretaçâo".

Assim, o "mundo significado" construído pelo sujeito comunicante e que se encontra contido num texto torna-se para vários sujeitos destinatários possíveis, de um lado, um mundo comumente significado (atividade de compreensáo) e, por outro lado, um mundo diversamente significado (atividade de interpretação), em que cada sujeito destinatário é um agente dessa diversificação.

Nesse contexto, se cada sujeito destinatário é um agente na construção dos sentidos de um texto, a leitura não pode ser entendida como aceitação passiva, mas como construção ativa. Cada leitura é uma nova escrita de um texto. $\mathrm{O}$ ato de criação não está somente na escrita, mas na leitura. Autor e leitor são produtores do texto. Um mesmo texto multiplica-se em infinitos textos, tantos textos quantas leituras houver. Cada leitura constituirá um novo texto, produto de determinaçóes múltiplas. Com isso, a leitura passa a ser concebida como um ato social entre leitor e autor, que participam de um processo interativo. O leitor constrói, e não recebe um significado pronto para o texto. Como afirma Martins (1994),

(...) a retomada do texto significa também uma nova postura diante dele; outras, o fato de termos interrompido a leitura não nos impede de mergulharmos novamente nela, como se narcotizados, mesmo havendo entáo emoçóes diferenciadas. (p. 61)

(...) há tantas leituras quantos são os leitores, há também uma nova leitura a cada aproximação do leitor com um mesmo texto, ainda quando mínimas as suas variaçôes. (...) (p. 79)

A releitura (...) pode apontar novas direçôes de modo a esclarecer dúvidas, evidenciar aspectos antes despercebidos ou subestimados, apurar a consciência crítica acerca do texto, propiciar novos elementos de comparação. (p. 85)

Assim, baseando-se numa concepção dialógica da língua, a leitura é vista como uma troca de sentidos entre os sujeitos. Esses sujeitos são vistos como 
estrategistas, construtores sociais, sujeitos ativos que dialogam, constroem-se e são construídos no texto. O sentido não é algo dado, pronto, mas é construído na interação texto-sujeitos, considerando-se, para tanto, as "sinalizaçôes" textuais dadas pelo sujeito comunicante e os conhecimentos do sujeito interpretante.

Pelo exposto, pode-se dizer que a leitura não é comparável a nenhum outro meio de aprendizagem e de comunicação, porque ela tem um ritmo que é governado pela vontade do leitor; abre espaços de interrogação, de meditação e de exame crítico, isto é, de liberdade; é uma correspondência não só com o livro, mas também com o mundo interior, através do mundo que o texto abre ao leitor.

A leitura crítica possibilita sair da alienação, obrigando o leitor a pensar, a questionar, pois se lê um texto a partir dos valores que a sociedade transmite. Ou seja, o homem lê como em geral vive, num processo permanente de interação entre sensações, emoções e pensamentos. Aprende-se a partir do momento em que o ser humano é capaz de reformular valores e opinióes, amadurecendo a cada nova leitura.

Segundo Sartre,

(...) o escritor (...) desvenda o mundo e especialmente o homem para outros homens, a fim de que estes assumam em face do objeto, assim posto a nu, a sua inteira responsabilidade. (...) a função do escritor é fazer com que ninguém possa ignorar o mundo e considerar-se inocente diante dele. E uma vez engajado no universo da linguagem, não pode nunca mais fingir que não sabe (...). (SARTRE, 1989, p. 21)

Com isso, ao ler um texto, o leitor é obrigado a tomar consciência de um fato. O homem faz a história, mas a história não lhe é transparente. Ler, então, não é mera decodificação de um aglomerado de palavras. Numa perspectiva ideal, aprende-se a ler para ler criticamente o mundo. Ler, portanto, é um ato político somente realizado pelo homem e exige uma constante capacidade de interação com o cotidiano do mundo que está à volta.

Assim, a leitura é um dos aspectos mais importantes para o homem como ponto de partida para a aquisição de conhecimento, meio de comu- 
nicação e socialização. Ela abre as portas para a criatividade e para a fantasia, indica caminhos.

O escritor traça uma imagem mais próxima do real e não a verdade sobre o real. O real é filtrado pelos seus valores e princípios. Não existe uma única leitura de um texto. Cabe ao leitor desvendar a ideologia que está implícita no texto, a fim de poder agir, fazer-se sujeito. A história da leitura é, então, a história de cada um dos leitores.

Se a leitura é a história de cada um dos leitores, qual o lugar dela na escola?

\section{A leitura na escola}

Leitura, texto e sentido fazem parte do processo de interpretação. Se não existe texto, seja ele verbal ou não verbal, não há leitura e muito menos produção de sentidos.

A primeira dificuldade que o professor enfrenta ao tentar trabalhar com os alunos estratégias de leitura que os levem a uma interpretação crítica é despertar neles o gosto pela leitura. A primeira barreira parece ser o próprio texto. Porém, "formar leitores, desenvolver competências em leitura e escrita é uma tarefa que a escola tem que priorizar e não pode sequer protelar." (ANTUNES, 2009, p. 201).

Diante dessa tarefa, o que fazer quando os alunos não manifestam interesse em ler? "Os meus alunos não gostam de ler e escrever" é, sem dúvida, a reclamação mais comum ouvida entre professores. Por que essa realidade? Por que a leitura ocupa um lugar cada vez menor no cotidiano das pessoas?

Ninguém gosta de fazer algo que acredita ser difícil demais, nem aquilo de que não consegue extrair sentido. É dessa forma que, geralmente, a tarefa de ler e escrever é vista e vivida em sala de aula: difícil demais, porque não faz sentido.

Segundo Antunes, "não se nasce com o gosto pela leitura, do mesmo modo que não se nasce com o gosto por coisa nenhuma. $\mathrm{O}$ ato de ler não é, pois, uma habilidade inata. (...) o gosto por ler literatura é aprendido por um estado de sedução, de fascínio, de encantamento. Um estado que precisa ser estimulado, exercitado e vivido.” (ANTUNES, 2009, p. 201)

Dessa forma, conversando com alunos de níveis de ensino diferentes, percebe-se que não gostam de ler, porque sabem que, ao final da leitura, terão 
de responder uma lista de questóes que não fazem sentido para eles. Em alguns casos, realmente, as perguntas não fazem sentido ${ }^{1}$; porém, na maioria das vezes, falta algum conhecimento por parte dos educandos para que possam chegar aos implícitos do texto.

No discurso popular, circula a seguinte frase: "Só se aprende a fazer, fazendo". Assim, de nada adianta estudar teorias sobre textos, se o aluno não praticar. Em sala de aula, como desenvolver nos alunos competências de leitura e escrita, se eles não têm o mínimo interesse em ler? Como fazer com que eles sintam prazer em ler e entender o que leem? O que o texto exige do leitor? Que se entende por texto? Que significa ler?

Magda Soares apud Dell'Isola afirma que

(...) a leitura não é uma atividade de mera decodificação, em que o leitor aprende, compreende e interpreta a "mensagem" do autor, mas é processo constitutivo do texto: é na interação autor/ leitor que o texto é construído, é produzido. Ou seja: o texto não preexiste à sua leitura, pois esta é construção ativa de um leitor que, de certa forma, "reescreve o texto", determinado por seu repertório de experiências individuais, sociais e culturais. (DELL'ISOLA, 2001, p. 8)

O livro didático de Língua Portuguesa, sendo uma das ferramentas e, talvez, a mais utilizada pelos professores, acaba não contribuindo muito na formação de leitores críticos, capazes de interpretarem o que leem. Remetendo a Silva (2005a, p. 82), ou se educa para a emancipação ou para a submissão. Se o aluno não consegue perceber o que está por trás do código linguístico em um texto e se o professor não se esforça para levá-lo a realizar tal operação, está educando para a submissão. Onde não há compreensão/interpretação, não há crítica.

Porém, a dificuldade em se trabalhar com a leitura aprofundada do texto nem sempre revela falta de interesse do professor, pois

se, para as atividades gramaticais, o professor dispóe de uma descrição precisa dos conteúdos que os alunos devem adquirir a

1 Para exemplificar, Marcuschi (2001, 1996) e Feres (2003) fazem uma análise crítica das perguntas de exercícios de interpretação trabalhados nas escolas. 
cada série, para as atividades de expressão escrita e oral, nas quais os saberes a se construir são infinitamente mais complexos, ele tem tido de se contentar com indicações muito sumárias. Tudo se passa como se a capacidade de produzir textos fosse um saber que a escola deve encorajar, para facilitar a aprendizagem, mas que nasce e se desenvolve fundamentalmente de maneira espontânea, sem que pudéssemos ensiná-la sistematicamente. (DOLZ; SCHNEUWLY, 2004, p. 50)

O trabalho escolar, no domínio da interpretação e produção de linguagem, faz-se sobre os gêneros. Eles constituem o instrumento de mediação de toda estratégia de ensino e o material de trabalho, necessário e inesgotável, para o ensino da textualidade. O problema está em como os professores trabalham esses variados gêneros textuais. Infelizmente, a prática tem mostrado que, em muitas salas de aula, o texto tem sido um pretexto para o ensino de gramática e não é explorado em suas múltiplas possibilidades de sentido.

Tal problema é detectado por muitos educadores e pesquisadores, como Kleiman, levando-a a afirmar que

se o aluno é capaz de decodificar o texto escrito, se ele é capaz de utilizar a informação sintática do texto na leitura, e se, ademais, ele já completou a aquisição da língua materna, as dificuldades que ele revela na compreensão do texto escrito são decorrentes de estratégias inadequadas de leitura. A prática mencionada, a utilizaçáo do texto como pretexto da aula de gramática, certamente contribui para a formação de estratégias de leitura inadequadas, pela ênfase que coloca nos aspectos sequenciais e distribucionais dos elementos linguísticos do texto, justamente aqueles elementos que não são constitutivos do texto enquanto unidade de significação. (KLEIMAN, 2004, p. 56)

Dessa forma, em se tratando de leitura e interpretação, tem-se por objeto de estudo o texto. Mas, o que se entende por texto?

Como afirma Koch, "um texto se constitui enquanto tal no momento em que os parceiros de uma atividade comunicativa global, diante de uma ma- 
nifestação linguística, pela atuação conjunta de uma complexa rede de fatores de ordem situacional, cognitiva, sociocultural e interacional são capazes de construir, para ela, determinado sentido.” (KOCH, 2007, p. 30),

De acordo com essa concepção de texto, o sentido não está no texto, mas é construído a partir dele, no curso de uma interação. Nesse contexto, os sujeitos são vistos como entidades psicossociais, ativos e que (re)produzem o social na medida em que participam ativamente da definição da situação na qual se acham engajados, e são atores na atualização das imagens e das representaçôes sem as quais a comunicação não poderia existir. Como assinala Meurer, “(...) sempre que alguém escreve há uma expectativa de que o texto produzido seja o reflexo de determinados discursos e que, portanto, espelhe as maneiras de falar ou escrever das diferentes instituiçóes que regulam a comunidade onde o indivíduo está inserido.” (MEURER, 1997, p. 17)

Assim, na concepção interacional (dialógica) da língua, os sujeitos são vistos como atores/construtores sociais, e o texto é o próprio lugar da interação. Nele, os sujeitos dialogam, constroem-se e são construídos. Dessa forma, no texto, há lugar para toda uma gama de implícitos, cabendo ao leitor decifrá-los.

Azeredo ao definir texto, também defende que o sentido faz parte de uma produção em parceria: “(...) o texto é um produto da atividade discursiva. Em um texto circulam, interagem e se integram formaçóes várias, explícitas ou implícitas, evidentes por si mesmas ou dependentes de interpretação. Por isso, um texto é necessariamente fruto de uma construção de sentido em que cooperam quem o enuncia e quem o recebe (...)" (AZEREDO, 2004, p.39)

A partir das conceituaçóes apresentadas, percebemos que o texto é considerado uma unidade significativa (tanto para quem o produz, como para quem o recebe).

Assim, o ato de ler, como afirma Silva, "sempre envolve apreensão, apropriação e transformação de significados, a partir de um documento escrito. Leitura sem compreensão e sem recriação do significado é pseudoleitura, (...)”. (SILVA, 2005b, p. 96)

E, o autor ainda expóe algumas dúvidas sobre o trabalho que é desenvolvido com o texto nas escolas: “(...) Será que as escolas propóem leituras que levam à compreensão e re-criação? (...) Será que as escolas possibilitam a reflexão e a tomada de posição, despertadas pelo ato de ler?" (SILVA, 2005b, p. 96) 
Não existem fórmulas mágicas para o ensino de qualquer disciplina. Se não existe um caminho novo, é preciso encontrar um jeito novo de caminhar. O caminho pode ser o mesmo, mas se as estratégias e os objetivos forem repensados, é possível obter resultados bem mais animadores no trabalho com a leitura na escola.

\section{Ensinar a ler para além do visível: teoria e prática}

Não basta que o aluno reconheça o sentido de língua, ou seja, o sentido linear das palavras e frases para que perceba a mensagem pretendida pelo sujeito que comunica, mas que penetre nas sutilezas do texto, isto é, chegue ao sentido de discurso, a fim de que reconheça as ideias que estáo implícitas no texto. Portanto, o leitor precisa ir além do significado literal das palavras para interpretar o que lê.

Para entender melhor a diferença entre sentido de lingua e sentido de discurso, podemos nos valer dos três níveis da competência linguística estabelecidos por Coseriu (1980, p. 93). Pode-se perceber que, embora sob ângulos de análise diferentes, os dois autores - Charaudeau e Coseriu - abordam a questão do "compreender" e do "interpretar" como sendo processos distintos, ainda que complementares.

Dessa forma, em contribuição aos estudos linguísticos, Coseriu (1980) identificou três níveis da linguagem, como atividade universalmente humana - o nível universal, o histórico e o individual.

No nível universal, a linguagem, considerada como atividade, é o falar em geral, não determinado historicamente. Corresponde ao saber elocucional que todos possuem. Refere-se à realidade extralinguística, ou seja, ao designado. Para se comunicar, o leitor precisa ter conhecimento dessa realidade extralinguística.

No nivel histórico, a linguagem como atividade é a língua concreta, tal como se manifesta no falar. É a língua como saber tradicional de uma comunidade, que recebe os significados atribuídos pelos falantes dessa comunidade. Trata-se do saber idiomático, ou seja, cada comunidade tem a sua própria língua.

Já no nivel individual, a linguagem como atividade é o discurso, isto é, o ato linguístico de um determinado indivíduo numa situação dada. Trata-se do saber expressivo, próprio de cada pessoa. É ainda neste nível que se constrói o sentido, a interpretação. 
Assim, em todo ato de comunicação se realizam e manifestam esses três tipos de saberes linguísticos, relativos aos três planos linguísticos, que, por sua vez, correspondem, ainda, a três tipos diferentes de conteúdo linguístico:

a) a designação (ou referência), que se refere à realidade extralinguistica e corresponde ao plano linguístico geral (universal) e ao saber elocucional;

b) o significado, que se refere ao conteúdo designado linguisticamente em uma determinada língua, vinculado ao plano linguístico particular (bistórico) e ao saber idiomático e, ainda,

c) o sentido, que é o dito no texto, ou seja, o conteúdo linguístico expresso por meio da designação e do significado; refere-se ao plano do discurso (individual) e ao saber expressivo (à competência textual).

Para chegar ao "sentido de discurso", o sujeito que interpreta precisa, portanto, realizar o processo interpretativo que consiste em determinar, no texto, as relaçôes significativas pretendidas pelo sujeito que comunica. $\mathrm{O}$ processo interpretativo, segundo Carvalho (1973, p. 351-2) compreende três fases: identificação das identidades linguísticas de que se compóe o texto, os respectivos valores significativos e a identificação da realidade designada.

Assim, o sentido não é construído apenas por intermédio da relação língua/mundo, mas pela relação que subordina a referência ao mundo (a proposicional) à intersubjetividade dos interlocutores: eu e tu (a relacional).

A significação, por sua vez, é construída por meio de dois espaços de produção de sentido (externo e interno) e de dois espaços enunciativos de produção (EU)/ interpretação (TU) com a interposição de uma avaliação. A linguagem não se reduz à articulação de alguns enunciados, mas é o resultado de uma ampla combinação textual que se articula sobre dois planos, o do enunciado e o da enunciação.

Diante disso, podemos dizer que a comunicação é um jogo. Depende de uma atividade estratégica (conjunto de estratégias discursivas) que considera as determinaçôes do quadro situacional. Além disso, o ato de linguagem é o produto da ação de seres psicossociais que são testemunhas, mais ou menos conscientes, das práticas sociais e das representaçóes imaginárias da comunidade a que pertencem. 
Segundo a teoria gerativa de Chomsky (apud CHARAUDEAU, 2001, p. 27), o ato de linguagem se constitui a partir de um "locutor-ouvinte-ideal" e de um processo simétrico entre aquele que o produz e aquele que o recebe e o decodifica. Isso significa dizer que o sujeito que comunica não está sozinho; há sempre o outro que pode estar presente, ou não, no ato da enunciação.

Nesse contexto, os processos de "compreender" e "interpretar" são processos ativos e criativos, porque aquele que compreende e interpreta participa do diálogo, continuando a criação de seu interlocutor. A cada palavra do outro fazemos corresponder uma série de palavras nossas, formando uma réplica. Para Bakhtin (2000), o sentido de um enunciado não está na palavra nem na alma do sujeito que comunica, assim como também não está na alma do sujeito que interpreta; o sentido de um enunciado é o efeito da interação entre esses dois sujeitos.

A fim de exemplificar um processo produtivo de leitura, propomos a análise de duas capas de revista, uma da Veja e outra da Isto É, que tratam de um mesmo tema - a imigração.

As capas foram publicadas na mesma semana, fazendo referência ao mesmo fato - a morte do pequeno Aylan de três anos.

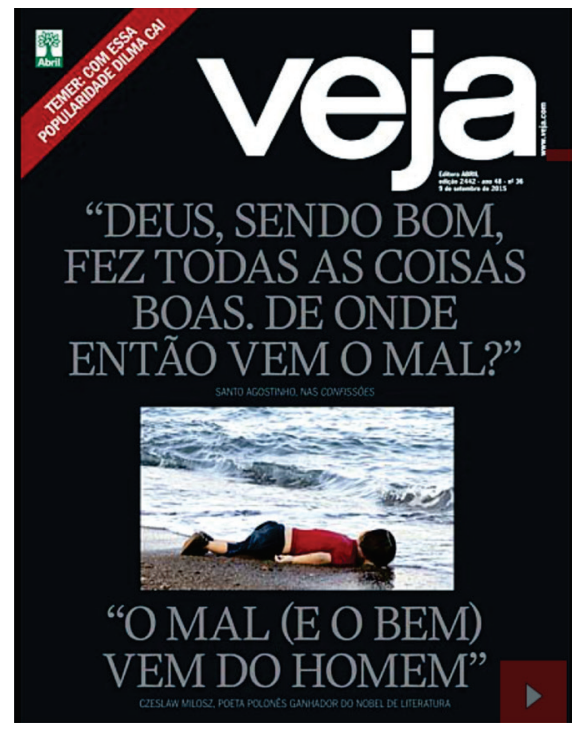

Fig.1: Revista Veja, 09/09/2015, ed. 2442. 


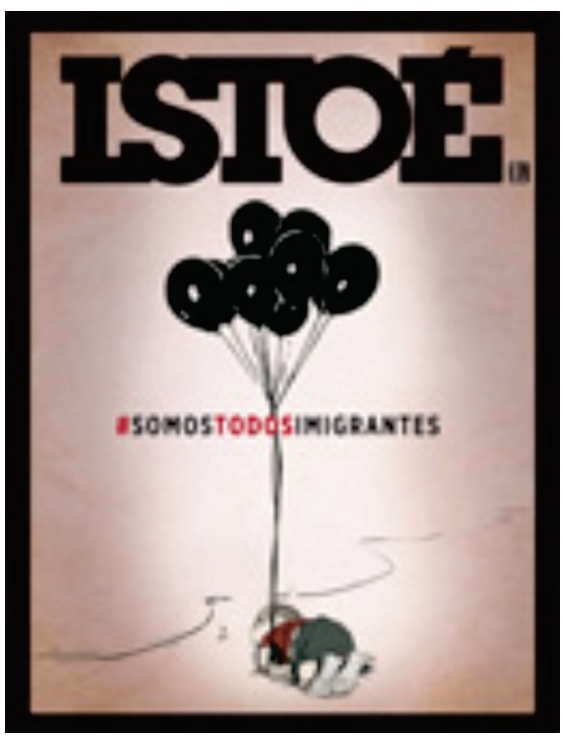

Fig.2: Revista Isto É, 09/09/2015, ed. 2388.

As duas revistas são informativas e abordam temas variados, com ênfase nos assuntos vinculados à política e à economia. Nas duas capas em análise, o tema principal é política internacional, mais especificamente, o difícil dilema dos refugiados.

As imagens estampadas nas capas não têm apenas função ilustrativa, ou meramente atrativa, mas contribuem na construção do sentido do texto como um todo e na percepção do real que se pretende levar ao leitor. Linguagem verbal e não verbal são articuladas a fim de produzirem uma interpretação ou um conceito sobre algo ou alguém.

A capa de uma revista constitui a embalagem de uma notícia, o primeiro elemento que o leitor tem contato. Essa embalagem pode antecipar determinadas informaçôes e até mesmo direcionar a leitura.

Fazendo uma leitura superficial, de busca do "sentido de língua", identificamos, na capa da Veja, a foto de uma criança jogada na areia da praia. Na capa da Isto É, há um desenho de uma criança também deitada na areia da praia, com vários balóes amarrados. A cor que predomina nas duas capas é o preto. Essa simples leitura, de "sentido de língua", não é suficiente para entendermos o(s) sentido(s) proposto(s) pelos dois veículos de comunicação. Muito mais que ilus- 
trar, uma manchete, uma foto ou um desenho colabora ou direciona a interpretação do fato. A imagem é também um texto que precisa ser lido, interpretado.

Uma imagem apresenta uma mensagem denotada, que procura imitar o real e outra conotada, fruto de escolhas, ediçóes. Segundo Joly,

quem já fabricou qualquer imagem sabe disso, mesmo com relação a tirar a fotografia mais comum. Fazer uma imagem é primeiro olhar, escolher, aprender. Não se trata "da reprodução de uma experiência visual, mas da reconstrução de uma estrutura modelo", que tomará forma de representação mais bem adaptada aos objetivos que estabelecemos para nós (...) (JOLY, 2012, p. 60),

Assim, para procedermos a uma leitura mais aprofundada, aquela que desvela, que busca o "sentido de discurso", precisamos recorrer ao contexto que gerou a produção das duas capas. A criança das duas capas é a mesma. Por quê? Por que o preto predomina? Por que a criança está inerte e sozinha?

$\mathrm{Na}$ escola, se o aluno não tem a prática da leitura, precisa ser estimulado e cabe ao professor orientá-lo nessa leitura mais aprofundada. O aluno precisa ser estimulado a questionar o texto, seja ele verbal ou não. Por exemplo, nas duas capas de revista em análise, o aluno poderia pesquisar a simbologia da cor preta, a intertextualidade presente na manchete da capa da Veja e assim por diante. Ler é muito mais que ver, como será evidenciado na análise proposta.

Para a criação de uma capa de revista, há um acontecimento bruto que precisa ser descrito e narrado, a fim de que seja transformado em "notícia", em "capa". Esse acontecimento bruto passa a um acontecimento interpretado no momento em que uma equipe faz escolhas, ou seja, seleciona um dentre tantos fatos para dar ênfase, escolhe a foto, faz ediçóes... São tantas interferências que o "real" passa a ser um "objeto construído".

As duas capas retratam um menino sírio chamado Aylan, de três anos, que morreu afogado em Bodrum, na Turquia, ao tentar atravessar o mar Mediterrâneo em um bote, para fugir da guerra com os seus pais e irmão. Apenas o pai sobreviveu. Aylan, o seu irmáo de cinco anos e a mãe morreram.

Aylan está de bruços. A posição horizontal do menino contribui para enfatizar a inércia do corpo, em oposição, por exemplo, ao movimento das ondas do mar na capa da Veja. Não é a imagem de uma criança que resolve deitar-se 
na areia, mas a imagem de alguém que é trazido pelo mar. Na capa da Veja é possível ver que as roupas estão molhadas, grudadas ao corpo. Dessa forma, a imagem de uma criança sozinha na praia é a própria imagem do abandono, da total fragilidade do ser humano. É o horror em retrato.

$\mathrm{Na}$ capa da Isto É, vários balóes de gás estão presos ao corpo do menino, como se fossem erguê-lo e tirá-lo dali.

O preto é a cor que predomina. Segundo Chevalier e Gheerbrant, o preto, "simbolicamente, é com mais frequência compreendido sob o seu aspecto frio, negativo. (...) O preto é a cor do luto; não como o branco, mais de uma maneira mais opressiva. (...)”. (CHEVALIER E GHEERBRANT, 2012, p. 740)

Assim, nas duas capas, é o preto que dá o tom da tragédia. Na capa da Veja, a única luz é a que ilumina o corpo do menino. Contrastando com o preto, há o branco do logo, chamando a atenção do leitor para a cena retratada.

$\mathrm{Na}$ capa da Isto É, até o logo está na cor preta. A luz também incide sobre o menino. Partindo do centro, a capa parte de um dégradê na cor cinza, até chegar ao preto da borda.

As duas revistas são produtos do campo jornalístico e procuram levar a informação ao leitor. Porém, em meio a tanta concorrência, o "como" levar a informação é muito importante. Assim, o que vemos não é a pura descrição do real, mas a encenação, a dramatização da informação. É preciso sensibilizar, comover o leitor, a fim de que ele compre a revista.

$\mathrm{Na}$ capa da Veja, as manchetes retomam dois outros textos. A primeira manchete: “Deus, sendo bom, fez todas as coisas boas. De onde então vem o mal?"” retoma um trecho do livro sétimo, capítulo V (Unde malum) de Santo Agostinho, das Confissóes.

A segunda manchete, resposta à primeira: “'O mal (e o bem) vem do homem", é o título de um poema do polonês Czeslaw Milosz, ganhador do Nobel de Literatura em 1980. No poema, o polonês diz que o bem e o mal só existem no homem e se a espécie deixar de existir, eles também desaparecerão.

Nas manchetes em foco, há o uso da intertextualidade explícita, pois é feita menção à fonte da citação. Por mais que a revista utilize a intertextualidade explícita, tendo em vista que faz a citação com a identificação da fonte, quando se retoma o discurso de outrem, o objetivo é contestar uma ideia ou reforçá-la. $\mathrm{Na}$ argumentação, a intertextualidade explícita é um recurso de autoridade.

A revista tenta levar o leitor a crer que a culpa por Aylan estar morto é do 
homem, que faz a guerra, que não acolheu a família de Aylan e tantas outras antes que fossem ceifadas... Ou seja, mesmo Deus sendo bom e fazendo coisas boas, como o homem, este não consegue ser bom como o seu criador e é o culpado pela origem do mal.

$\mathrm{Na}$ capa, a explicação para a origem do mal se baseia na afirmação de um poeta que é confirmada pela revista. A causa do mal não é uma hipótese, uma suposição, mas uma realidade presentificada pela foto. Ou seja, a explicação para a origem do mal é resultado da experiência real.

Por mais que a revista forneça uma resposta para a pergunta colocada pela manchete, num primeiro momento, faz o leitor refletir, tendo em vista que a foto do menino ocupa o centro da capa. Que mãe ou que pai não pensaria que poderia ser o próprio filho naquela situação?

$\mathrm{Na}$ capa da Isto É, há também a reprodução de uma imagem, aqui uma charge, que circulou nas mídias sociais. A manchete simplesmente afirma: "Somos todos imigrantes". O verbo na primeira pessoa do plural inclui não apenas a revista, mas também o leitor, levando-o a se colocar no lugar de tantos imigrantes que lutam pelo direito de viver. Não apenas o pequeno menino Aylan era um imigrante; eu, você, todos somos imigrantes.

Incluir o leitor no texto é também uma estratégia de persuasão, de sensibilização. A Veja provoca o leitor com uma pergunta; a Isto É, com o uso da primeira pessoa do plural, procura tirar o leitor da passividade, convidando-o a sentir também a dor da tragédia, e evidencia o ponto de vista daquele que enuncia.

Interessante observar que, em meio a uma capa em que o preto dá o tom da tragédia, o vermelho é utilizado para destacar a palavra "todos" da manchete, a mesma cor da camisa que o menino usava no dia do afogamento.

Nas duas capas, o mar traz em si tanto a metáfora da esperança de uma travessia para uma vida melhor quanto a dos perigos de um mergulho na incerteza.

Assim, as escolhas que resultaram na construção da capa mostram muito mais que uma pequena criança, transformam um mundo bruto em um mundo significado, manchado pela falta de amor, de paz, de responsabilidade... dos humanos.

\section{Considerações finais}

A partir das análises propostas, é possível perceber que, metaforicamente, a leitura pode ser entendida como um passaporte para a interação com o 
mundo. No termo passaporte, subentende-se "permissão legítima”, o que nos leva a ver a leitura - não apenas da palavra (sentido de língua), mas do mundo (sentido de discurso) - como um meio ou, talvez, o meio de interação legítima do leitor com o mundo. A falta de leitura pode imobilizar o homem no sentido de que ele terá mais dificuldade para entender o mundo e tomar a sua palavra.

Além disso, se queremos que o aluno ultrapasse o "sentido de lingua" e chegue ao "sentido de discurso" (Charaudeau, 1995, 1999), precisamos criar oportunidades para que isso ocorra. Este precisa ler textos que o instiguem a procurar pistas, indícios que o levem a descobrir sentido(s).

Se o aluno for habituado à prática da leitura, estará não só desenvolvendo a habilidade de apreensão do(s) sentido(s) dos textos, assim como percebendo que podemos nos expressar de várias formas e, com isso, obtermos efeitos de sentido diferentes. Concordamos com Antunes quando diz que

(...) se desde o início, for dada aos alunos a oportunidade da leitura plena (do livro e do mundo) - aquela que desvenda, que revela, que lhes possibilita uma visão crítica do mundo e de si mesmos - se lhes for dada a oportunidade da leitura plena, repito, uma nova ordem de cidadãos poderá surgir e, dela, uma nova configuração de sociedade. (ANTUNES, 2009, p. 206)

Esperamos, assim, com este artigo, fomentar a discussão em torno da leitura na escola, tendo em vista que "o compromisso primeiro do professor de língua materna é auxiliar o aluno a tornar-se um leitor autônomo e um produtor competente de textos”. (FIORIN, 1996, p. 9)

\section{Referências}

ANTUNES, Irandé. Lingua, texto e ensino: outra escola é possível. São Paulo: Parábola Editorial, 2009.

AZEREDO, José Carlos de. Fundamentos de gramática do português. 3.ed. Rio de Janeiro: Jorge Zahar Editor, 2004.

BAKHTIN, Mikhail. Estética da criação verbal. São Paulo: Martins Fontes, 2000.

CARVALHO, José G. Herculano de. Teoria da linguagem: a natureza do fenômeno linguístico e a análise das línguas. Tomo I. 3a tiragem. Coimbra: Atlântida Editora, 1973. 
CHARAUDEAU, Patrick. Uma teoria dos sujeitos da linguagem. In: MARI, H. et al. Análise do discurso: fundamentos e práticas. Belo Horizonte: Núcleo de Análise do Discurso - FALE / UFMG, 2001.

Análise do discurso: controvérsias e perspectivas. In: MARI, H. et al. (Orgs.). Fundamentos e dimensóes da Análise do Discurso. Belo Horizonte: Carol Borges - Núcleo de Análise do Discurso. Fale - UFMG, 1999.

- Les conditions de compréhension du sens de discours. In : Anais do I Encontro Franco-Brasileiro de Análise do Discurso. Rio de Janeiro: UFRJ, 1995.

CHEVALIER, Jean; GHEERBRANT, Alain. Dicionário de simbolos: mitos, sonhos, costumes, gestos, formas, figuras, cores, números. 26. ed. Rio de Janeiro: José Olympio, 2012.

COSERIU, Eugenio. Liçôes de linguística geral. Rio de Janeiro: Ao Livro Técnico, 1980.

DELL'ISOLA, Regina Lúcia Péret. Leitura: inferências e contexto sociocultural. Belo Horizonte: Formato Editorial, 2001.

DOLZ, Joaquim; SCHNEUWLY, Bernard e colaboradores. Gêneros orais e escritos na escola. Trad. e org. Roxane Rojo e Glaís Sales Cordeiro. Campinas, SP: Mercado de Letras, 2004.

FERES, Beatriz dos Santos. A escola "faz questão" de leitores autômatos ou autônomos? A atividade de leitura no Ensino Fundamental. Dissertação de Mestrado em Letras. Niterói: UFF, Instituto de Letras, 2003.

FIORIN, José Luís. Teorias do discurso e ensino da leitura e da redação. Niterói: EDUFF, 1996, p. 5-27.

JOLY, Martine. Introdução à análise da imagem. Trad. Marina Appenzeller. 14. ed. São Paulo: Papirus, 2012.

KLEIMAN, Ângela B. (Org.). Leitura: ensino e pesquisa. 2. ed. Campinas: Pontes, 2004.

$\mathrm{KOCH}$, Ingedore G. Villaça. O texto e a construção dos sentidos. 9. ed. São Paulo: Contexto, 2007.

MARCUSCHI, Luiz Antônio. Compreensão de texto: algumas reflexôes. In: DIONÍSIO, Ângela Paiva; BEZERRA, Maria Auxiliadora (Orgs.) O livro didático de português: múltiplos olhares. Rio de Janeiro: Lucerna, 2001. . Exercícios de compreensão ou copiação. Brasília, jan./mar. 1996, p. 61-82.

MARTINS, Maria Helena. O que é leitura. São Paulo: Brasiliense, 1994. 
MEURER, José Luiz. Esboço de um modelo de produção de textos. In: MEURER, José Luiz; MOTTA-ROTH, Désirée (Orgs.). Parâmetros de textualização. Santa Maria: Ed. da UFSM, 1997.

SARTRE, Jean-Paul. Que é literatura? Trad. Carlos Felipe Moisés. São Paulo: Ática, 1989.

SILVA, Ezequiel T. da. Elementos de pedagogia da leitura. São Paulo: Martins Fontes, 2005a.

. $O$ ato de ler: fundamentos psicológicos para uma nova pedagogia da leitura. 10.ed. São Paulo: Cortez, 2005b.

WEBLIOGRAFIA

REVISTA VEJA. Disponível em <http://veja.abril.com.br/acervodigital/ home.aspx>. Acesso em 20/09/2015.

REVISTA ISTO É. Disponível em< http://www.istoe.com.br/revista/edicoes-anteriores/> Acesso em 20/09/2015.

\title{
TEACHING TO READ BEYOND THE VIEW: FROM THE SENSE OF LANGUAGE TO THE SENSE OF DISCOURSE
}

\begin{abstract}
This paper has as objective, from the analysis of two magazine covers, show that reading a text is not only giving a sense to it, but realizing its multiple meanings. So, in addition to contributions to Textual Linguistics, we also take base some contributions from Semiolinguistics, for example, the notion of "sense of language" and "sense of discourse" proposed by Charaudeau.
\end{abstract}

KEYWORDS: reading; interpretation; magazine covers.

Recebido em: 20/10/2015

Aprovado em: 29/15/2016 